Article

\title{
The Preparation of H13 Steel for TBM Cutter and the Performance Test Close to Working Condition
}

\author{
Yong Hu ${ }^{1}$, Jiyu Tian ${ }^{1}$, Mingxu Xu ${ }^{1}$, Hongwei Zhao ${ }^{1}$, Mingze Wang ${ }^{2}$, Maosen Wang ${ }^{3, *}$ \\ and Aiwu Zhang ${ }^{4}$ \\ 1 School of Mechanical and Aerospace Engineering, Jilin University, Changchun 130025, China; \\ huyong@jlu.edu.cn (Y.H.); jytian17@mails.jlu.edu.cn (J.T.); xmx@jlu.edu.cn (M.X.); tian13711@126.com (H.Z.) \\ 2 School of Material Science and Engineering, Jilin University, Changchun 130025, China; \\ xiuhua2010888@sina.com \\ 3 School of Construction Engineering, Jilin University, Changchun 130026, China \\ 4 Welter Tunnel Equipment Co., Ltd., Jilin 132000, China; 7787700778@163.com \\ * Correspondence: wangms@jlu.edu.cn; Tel.: +86-136-0432-0028
}

Received: 6 September 2018; Accepted: 9 October 2018; Published: 11 October 2018

\begin{abstract}
The material of disc cutters is important to full-face tunnel boring machines (TBM). In recent years, disc cutters were optimized and tested by many scholars all around the world. $\mathrm{H} 13$ (4Cr5MoSiV1) steel is widely used due to its excellent properties, especially in TBM disc cutters. In this paper, H13 steel with optimized composition was prepared and heat treatment. The high temperature compression of $\mathrm{H} 13$ steel was conducted at the temperatures ranging from $100{ }^{\circ} \mathrm{C}$ to $700{ }^{\circ} \mathrm{C}$, with strain rate at $0.01 \mathrm{~s}^{-1}$. The stress-strain curves, Rockwell hardness and microstructure of $\mathrm{H} 13$ steel after compression were obtained and analyzed. The results showed that the compression strength and hardness decreased as the temperature increased; and the compression strength, hardness and ductility decreased rapidly between $600{ }^{\circ} \mathrm{C}$ and $700{ }^{\circ} \mathrm{C}, \mathrm{HR}_{700}$ (the hardness of $\mathrm{H} 13$ steel at $700{ }^{\circ} \mathrm{C}$ ) only reached $33.23 \mathrm{HRC}$. It is not recommended for TBM disc cutters to work in an environment over $600^{\circ} \mathrm{C}$.
\end{abstract}

Keywords: H13 steel; TBM disc cutter; high temperature compression; hardness

\section{Introduction}

A Full-face tunnel boring machine (TBM) is a large tunnel construction operating system integrating mechanical, hydraulic, electronic, and laser technologies. Compared with the traditional method of drilling and blasting, TBM has the characteristics of fast construction, a short construction period, good working environment and high comprehensive benefits, so it has been widely used in tunnel construction [1-4].

The main tool for TBM rock breaking is the disc cutters, which are mounted on the cutter head, and the consumption is extremely high due to the poor working conditions, in such conditions, the partial temperature could exceed $600^{\circ} \mathrm{C}$ [5-7]. In order to reduce the consumption of the cutters, the cutter material needs to have high hardness, high wear resistance, good impact toughness, a certain resistance to tempering performance and a good processing performance [8].

H13 steel is a C-Cr-Mo-Si-V steel, which is widely used around the world [9-11]. Meanwhile, Extensive research have been conducted to explore the optimization of the chemical composition of H13 steel. H13 steel has high thermal strength, hardenability, wear resistance and hardness, and has good toughness and thermal fatigue at moderate temperatures [12-14]. Many TBM companies have produced $\mathrm{H} 13$ steel as a cutter material. 
In this study, the H13 steel was prepared and the working condition was simulated at high temperature compression. The effects of temperature, compression stress-strain curves, hardness and microstructure on H13 steel were analyzed. It is believed that the results will serve as a guide for efficient selection and production of TBM disc cutters.

\section{Materials and Methods}

\subsection{The Initial Microstructure and Heat Treatment}

The as-cast H13 steel in this study was smelted by the Medium frequency induction furnace (Atmosphere Protection) (Zhuzhou Shuangling Technology Co., Ltd., Zhuzhou, China) and the Vacuum electroslag furnace (Zhuzhou Shuangling Technology Co., Ltd., Zhuzhou, China) [15]. The chemical composition (wt.\%) of as-received H13 steel is shown in Table 1.

Table 1. The chemical composition of H13 steel (wt.\%).

\begin{tabular}{cccccccccc}
\hline $\mathbf{C}$ & $\mathbf{S i}$ & $\mathbf{M n}$ & $\mathbf{P}$ & $\mathbf{S}$ & $\mathbf{C r}$ & Mo & $\mathbf{V}$ & Co & Ni \\
\hline 0.44 & 0.93 & 0.46 & 0.018 & 0.007 & 5.02 & 1.37 & 1.02 & 0.03 & 0.13 \\
\hline
\end{tabular}

The heat treatment process application is shown in Figure 1. The as-cast H13 steel was firstly preheated and retained at $700{ }^{\circ} \mathrm{C}$ for $60 \mathrm{~min}$ inside a vacuum furnace, then it was heated up to $1050{ }^{\circ} \mathrm{C}$, and held up for $45 \mathrm{~min}$ for quenching, followed by oil-cooling to $60^{\circ} \mathrm{C}$. After the quenching process, the steel was reheated and retained at $580{ }^{\circ} \mathrm{C}$ for $120 \mathrm{~min}$, followed by air-cooling to room temperature inside the furnace $[16,17]$.

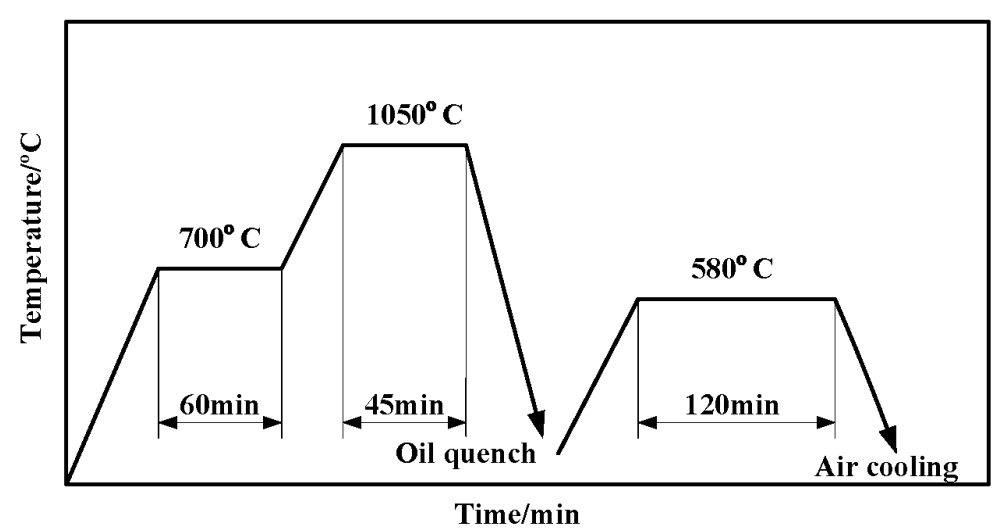

Figure 1. Quenching-tempering heat treatment process curve.

The specimens for compression and metallographic observation were machined from as-casted steel and heat treatment steel mentioned above. The metallographic specimens were polished and corrosion in the concentration $4 \%$ of nitric alcohol solution for about $1 \mathrm{~min}$ at room temperature, which was observed by OLYMPUS DSX500 microscope (Olympus Corporation, Tokyo, Japan).

Figure 2 shows the microstructure of initial as-cast and heat treatment H13 steel. It can be seen in Figure 2a, there exists segregation in the as-cast $\mathrm{H} 13$ steel. The microstructure was not uniform, and pseudo-eutectic carbides were present in the segregation zone of the black alloy elements [18]. After quenching and tempering of H13 steel, the coarse columnar crystals and dendrites in the as-cast microstructure were crushed, and the pseudo-eutectic carbides were broken and partially dissolved in the matrix. By comparing Figure $2 a, b$, it could be seen that under the effect of temperature and pressure, the diffusion rate of atoms was accelerated, the segregation was effectively improved, and the chemical composition became uniform after a long time of thermal insulation. The organization was mainly based on small lath tempered martensite. 

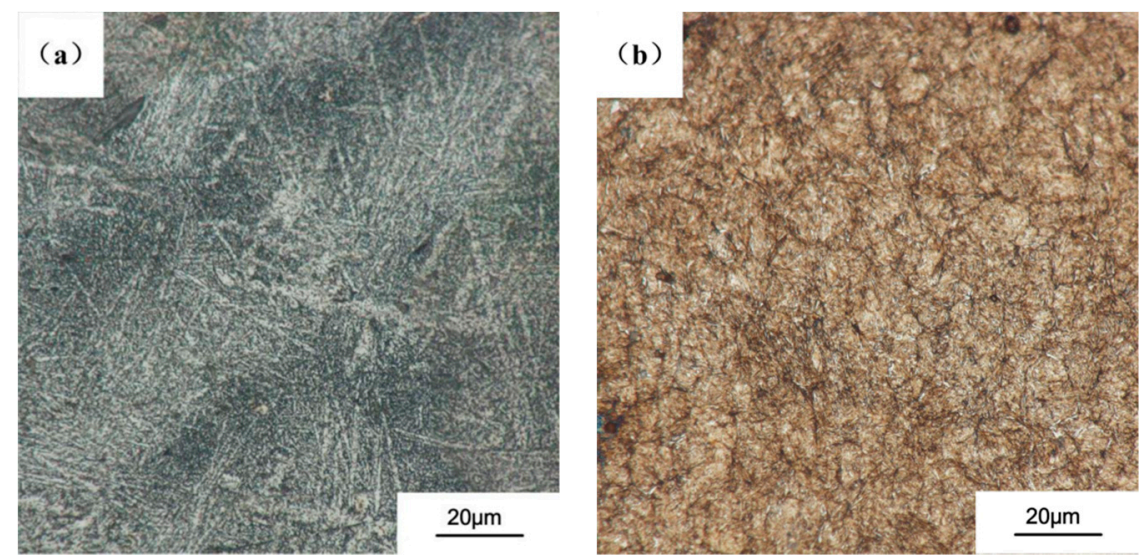

Figure 2. Microstructure of H13 steel: (a) As-cast; (b) heat treatment.

\subsection{The Condition of High Temperature Compression Test}

Figure 3 is an illustration of the high temperature compression tester produced by Sinotest Equipment Co., ltd. (DDL10, Changchun, China). A special plate with a hardness greater than 65 HRC was adopted during compression. The test procedure and specimens for high temperature compression are also shown in Figure 3.

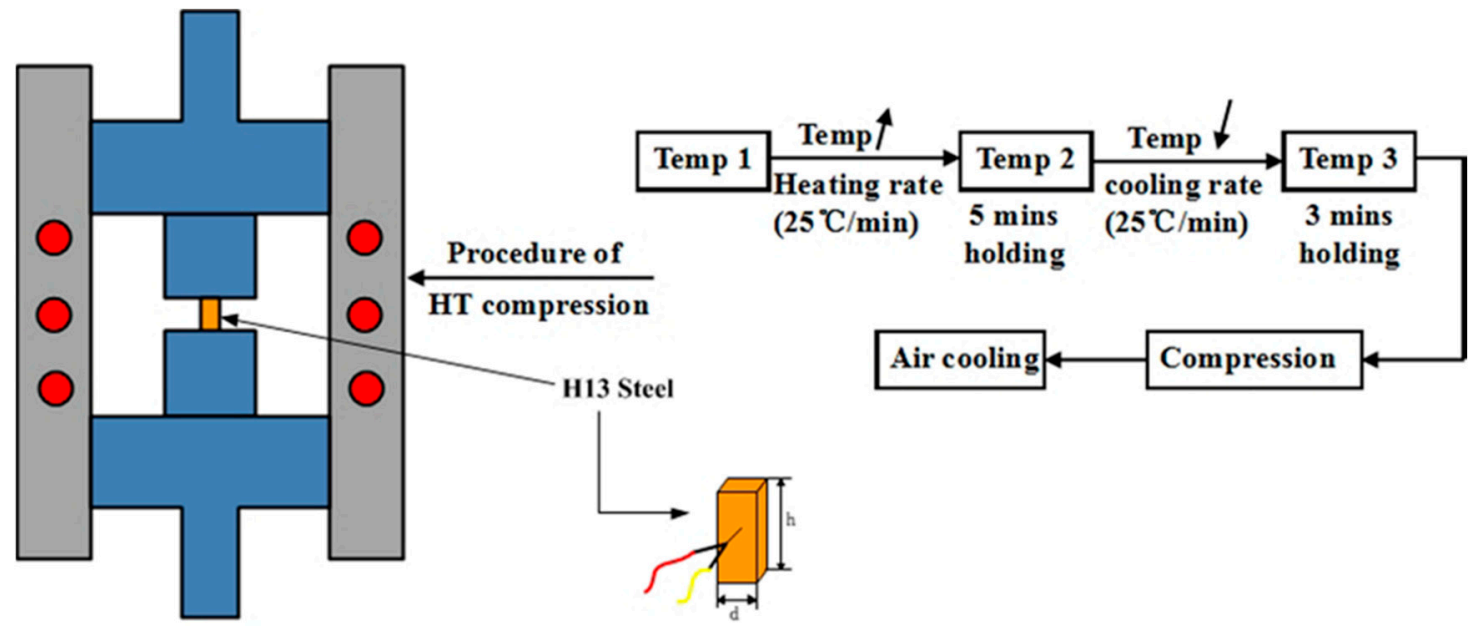

Figure 3. Compression tester and specimen for high temperature compression.

The size of specimens for compression is $5 \times 5 \times 10 \mathrm{~mm}$, considering the work and failure conditions of TBM cutter comprehensively, the specimens were compressed to a strain of 0.25 . First, the specimens (as-cast and heat treatment) were placed in the compression tester and compressed under room temperature. Then, the high temperature compression tests started, the steps of each test showed as follows: Temp 1 indicates the room temperature, Temp 2 indicates the temperature after heated and Temp 3 indicates the test temperature. The specimens (heat treatment) were heated to Temp $2\left(50{ }^{\circ} \mathrm{C}\right.$ higher than Temp 3 of $100-700{ }^{\circ} \mathrm{C}$ with a $100{ }^{\circ} \mathrm{C}$ interval at $25^{\circ} \mathrm{C} / \mathrm{min}$ and held for $5 \mathrm{~min}$ ), after that, the temperature was adjusted back to Temp 3 at $25^{\circ} \mathrm{C} / \mathrm{min}$ and held for $3 \mathrm{~min}$ to get a uniform temperature distribution. Finally, the specimens were compressed to a strain of 0.25 under Temp 3 and strain rates of $0.01 \mathrm{~s}^{-1}$, followed by air-cooling to Temp 1 inside the compression tester and the test ended. After the high temperature compression, the specimens were cut lengthwise, polished and corrosion, then, optical microscopes were used to observe the structural changes in the specimens. 


\subsection{Mechanical Properties}

The mechanical strength of the specimens was measured through hardness tests and the high temperature compression tests above. Hardness was measured in terms of Rockwell hardness, taking several points in the upper, the middle and lower part of specimens after high temperature compression, and the average was obtained by measuring specimens for 5 times per test condition.

\section{Results}

\subsection{Analysis of Compression Curve}

The stress-strain curves of $\mathrm{H} 13$ specimens (as-cast and heat treatment) at room temperature are shown in Figure 4. It could be seen from Figure 4 that the mechanical properties of the H13 steel after heat treatment have been significantly improved. Its maximum compression strength $\left(\sigma_{\mathrm{c}}\right)$ is about four times that of the as-cast steel, which reached $2700 \mathrm{MPa}$, and shows that the elastic limit has also been greatly improved. However, the ductility of the H13 steel after heat treatment is poor, the reason leading to this phenomenon is the high hardness and high strength of the mechanical properties of tempered martensite, while due to the brittle phase of the tempered martensite, it resulted in the increased strength but decreased the ductility. At the same time, due to the presence of tempered troostite, the elastic limit and yield limit of the material were increased, and a certain degree of toughness also appeared. This meets the requirements of the high strength and high elastic limit of the TBM cutter.

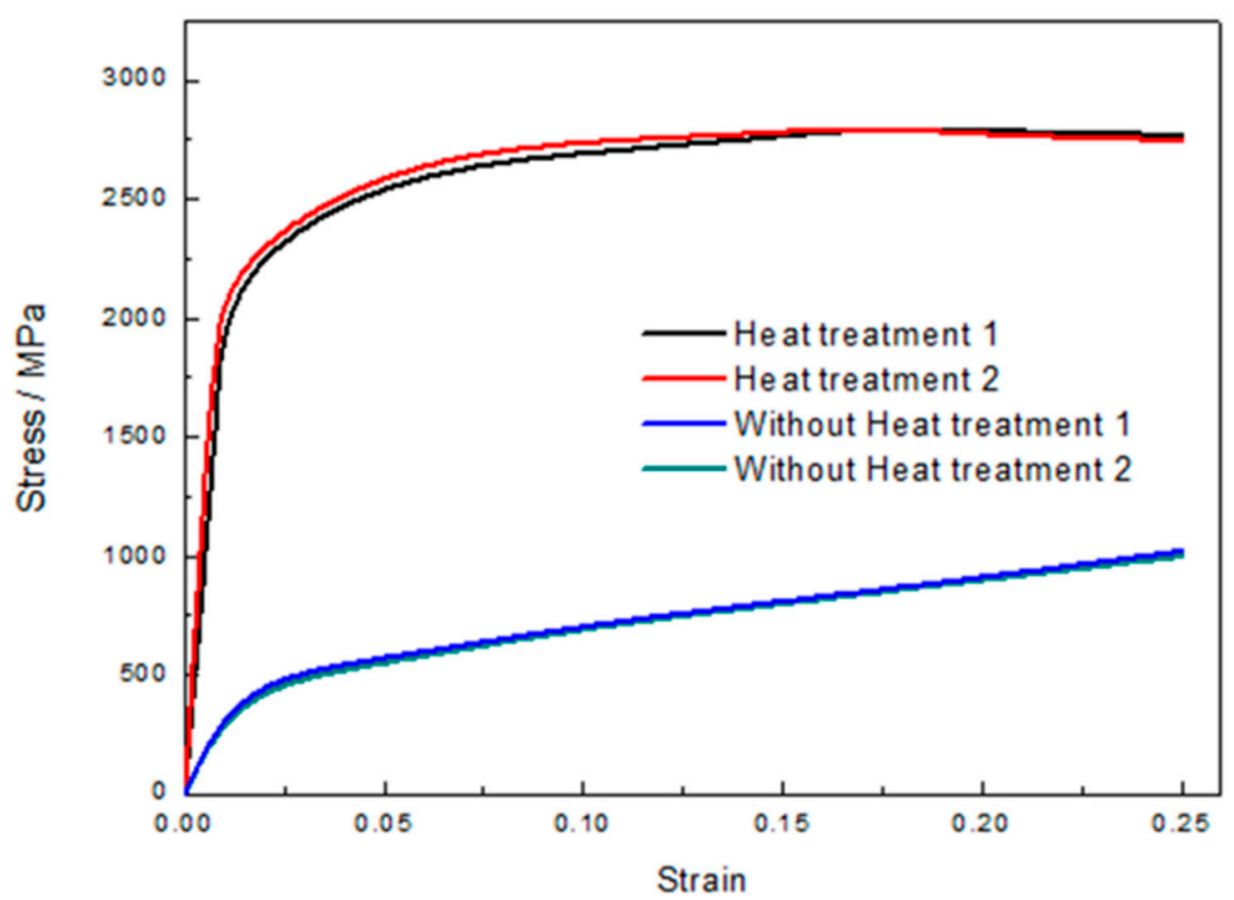

Figure 4. Stress-strain curve of $\mathrm{H} 13$ steel at room temperature.

The stress-strain curves of $\mathrm{H} 13$ specimens (heat treatment) at high temperature are shown in Figure 5. It could be seen from Figure 5 that the compression strength, overall, decreased as the temperature increased, and the reduction of the stress between $100{ }^{\circ} \mathrm{C}$ and $500{ }^{\circ} \mathrm{C}$ was relatively small; when the temperature was raised to $600{ }^{\circ} \mathrm{C}$, the compression strength, the elastic limit and ductility decreased rapidly, and the brittleness appeared. The brittleness of $\mathrm{H} 13$ steel resulted in serious deterioration of the mechanical properties of steel, making it difficult to be used in the range of brittle temperatures and would easily get damaged which will affect practical work; when the temperature was raised to $700{ }^{\circ} \mathrm{C}$, the $\sigma_{\mathrm{c} 700}$ only reached $480 \mathrm{MPa}$, but ductility of the material was restored. 


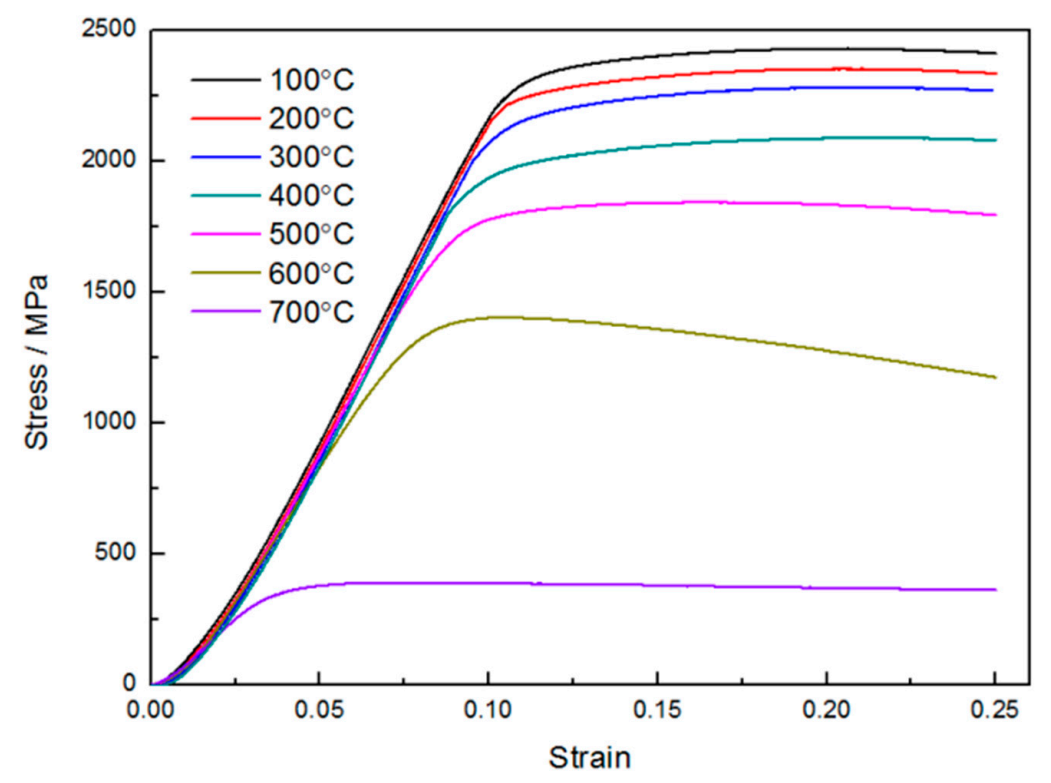

Figure 5. Stress-strain curve of H13 steel at high temperature.

In order to explore the mechanical properties of $\mathrm{H} 13$ steel between $600-700{ }^{\circ} \mathrm{C}$, three groups of compression tests $\left(630^{\circ} \mathrm{C}, 650^{\circ} \mathrm{C}\right.$ and $\left.670^{\circ} \mathrm{C}\right)$ were added. The results of curves are shown in Figure 6 .

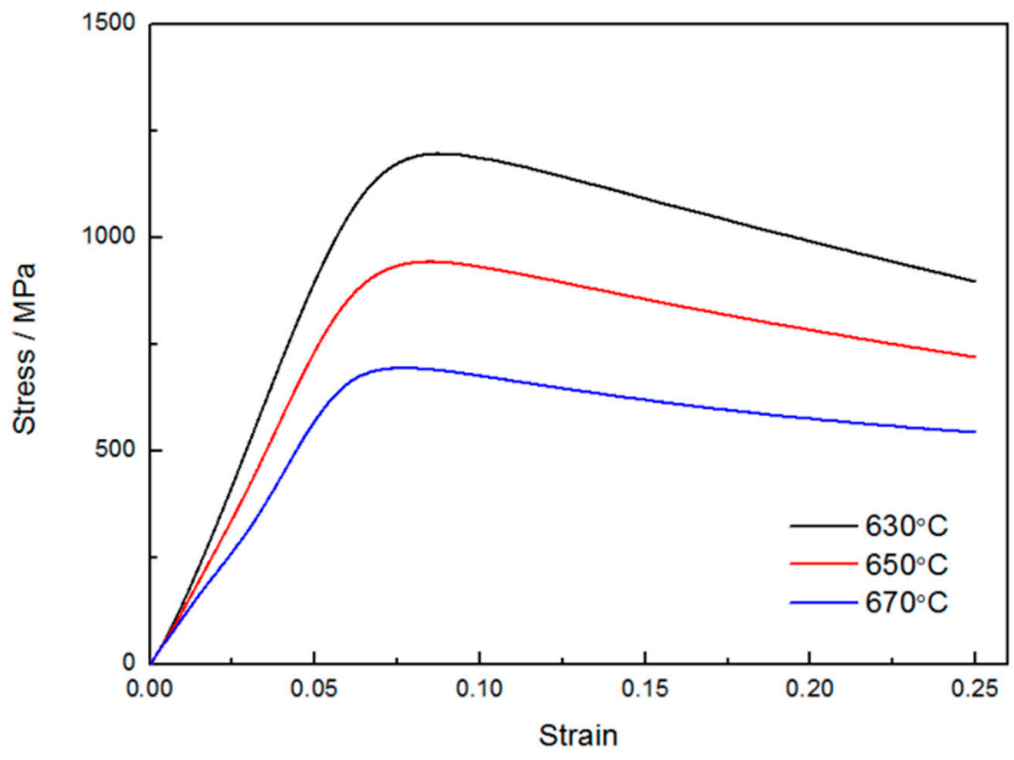

Figure 6. Stress-strain curve of $\mathrm{H} 13$ steel at $630^{\circ} \mathrm{C}, 650^{\circ} \mathrm{C}$ and $670{ }^{\circ} \mathrm{C}$.

As shown in Figure 6, the overall trend of the compression strengths at $630^{\circ} \mathrm{C}, 650{ }^{\circ} \mathrm{C}$ and $670{ }^{\circ} \mathrm{C}$ were similar to the one at $600{ }^{\circ} \mathrm{C}$, which decreased rapidly as the temperature increased, as the ductility also decreased rapidly.

The reason which might cause the above phenomenon could be the high temperature compression of $\mathrm{H} 13$ steel leading to the tempered martensite decomposition, the continuous precipitation of carbide and the decrease of the ductility and strength.

\subsection{Analysis of Hardness}

The results of the Rockwell hardness of $\mathrm{H} 13$ specimens after high temperature compression are shown in Figure 7. As shown in Figure 7, the hardness decreased with the increase of compression 
temperature, which showed the reduction of the hardness between $100{ }^{\circ} \mathrm{C}$ and $500{ }^{\circ} \mathrm{C}$ was relatively small. In this test, the $\mathrm{HR}_{100}$ reached $58.21 \mathrm{HRC}$, and $\mathrm{HR}_{500}$ reached $55.46 \mathrm{HRC}$. When the temperature was raised to $600{ }^{\circ} \mathrm{C}$, the hardness decreased rapidly, and when the temperature was raised to $700{ }^{\circ} \mathrm{C}$, $\mathrm{HR}_{700}$ only reached $33.23 \mathrm{HRC}$, and the organization is mainly based on tempered sorbite.

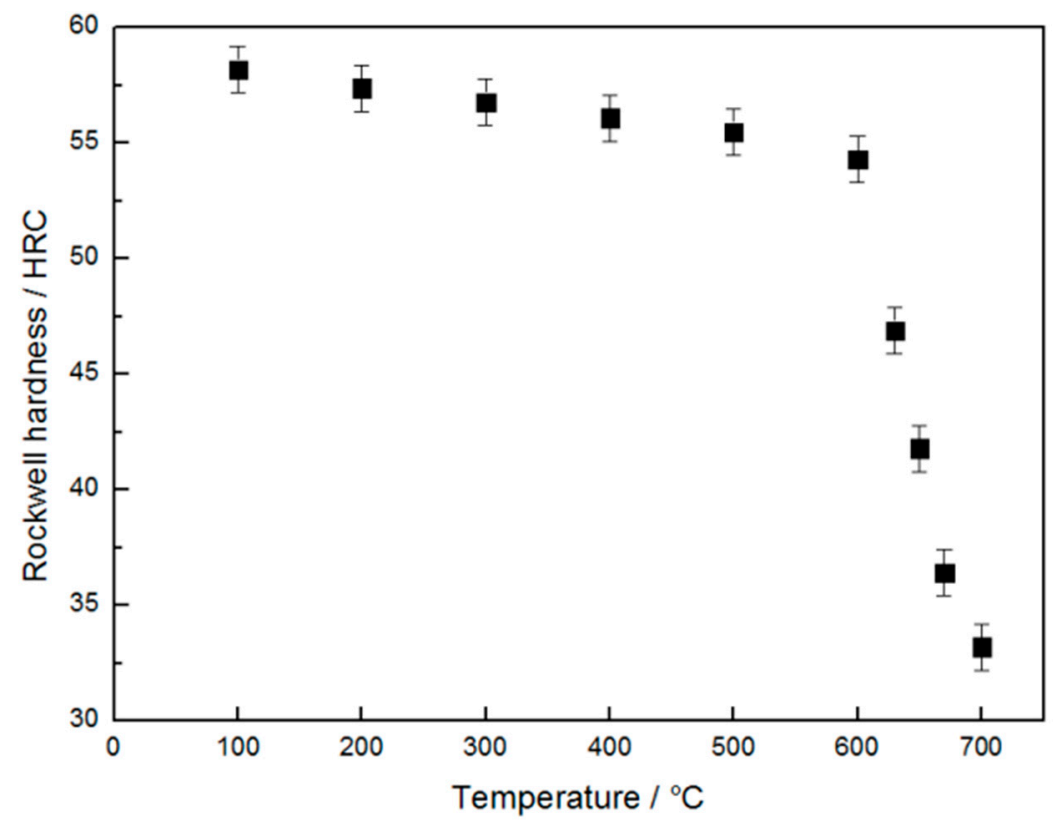

Figure 7. Rockwell hardness of H13 steel at high temperature.

\subsection{Analysis of Microstructure}

In order to further analyze the results, Figure 8 shows the microstructure of $\mathrm{H} 13$ steel compressed to a strain of 0.25 under a strain rate of $0.01 \mathrm{~s}^{-1}$ from $500{ }^{\circ} \mathrm{C}$ to $700{ }^{\circ} \mathrm{C}$. Due to the excellent alloy ratio, tissues and grains were refined. Meanwhile, special carbides were formed because of alloying elements, the expansion of carbon atoms was hindered, and the decomposition of martensite was delayed. It could be seen that as the temperature increased, the martensite content gradually decreased. When the temperature reached $600{ }^{\circ} \mathrm{C}$, as shown in Figure $8 \mathrm{~b}$, the alloying elements in the sample were segregated at the grain boundary, so that the grain boundary embrittled, and led to a decrease in material ductility. As the temperature continued to rise, the segregation grew, aggregated, and spheroidized, which restored the ductility of the material.
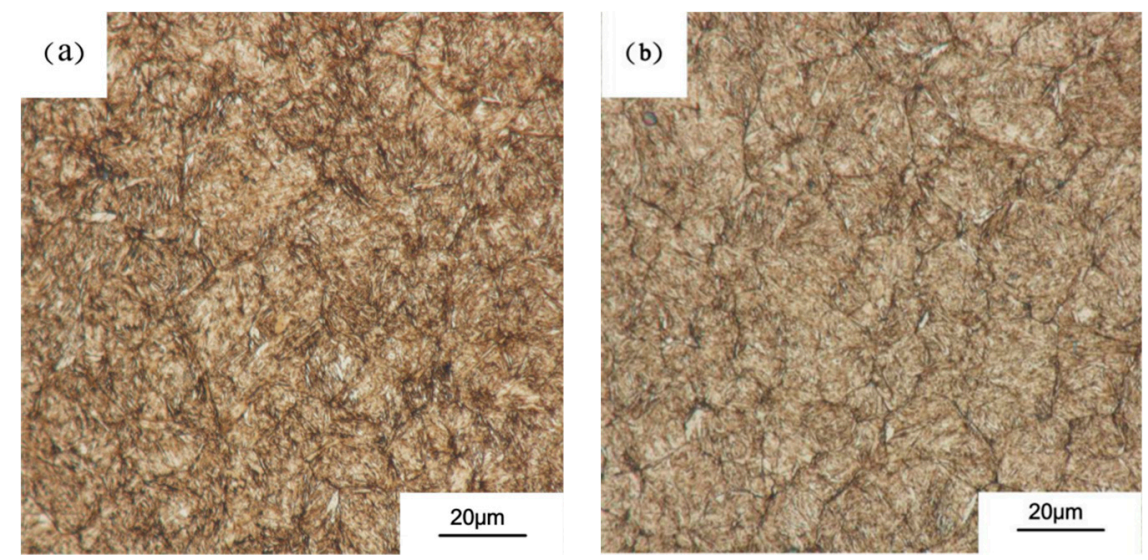

Figure 8. Cont. 

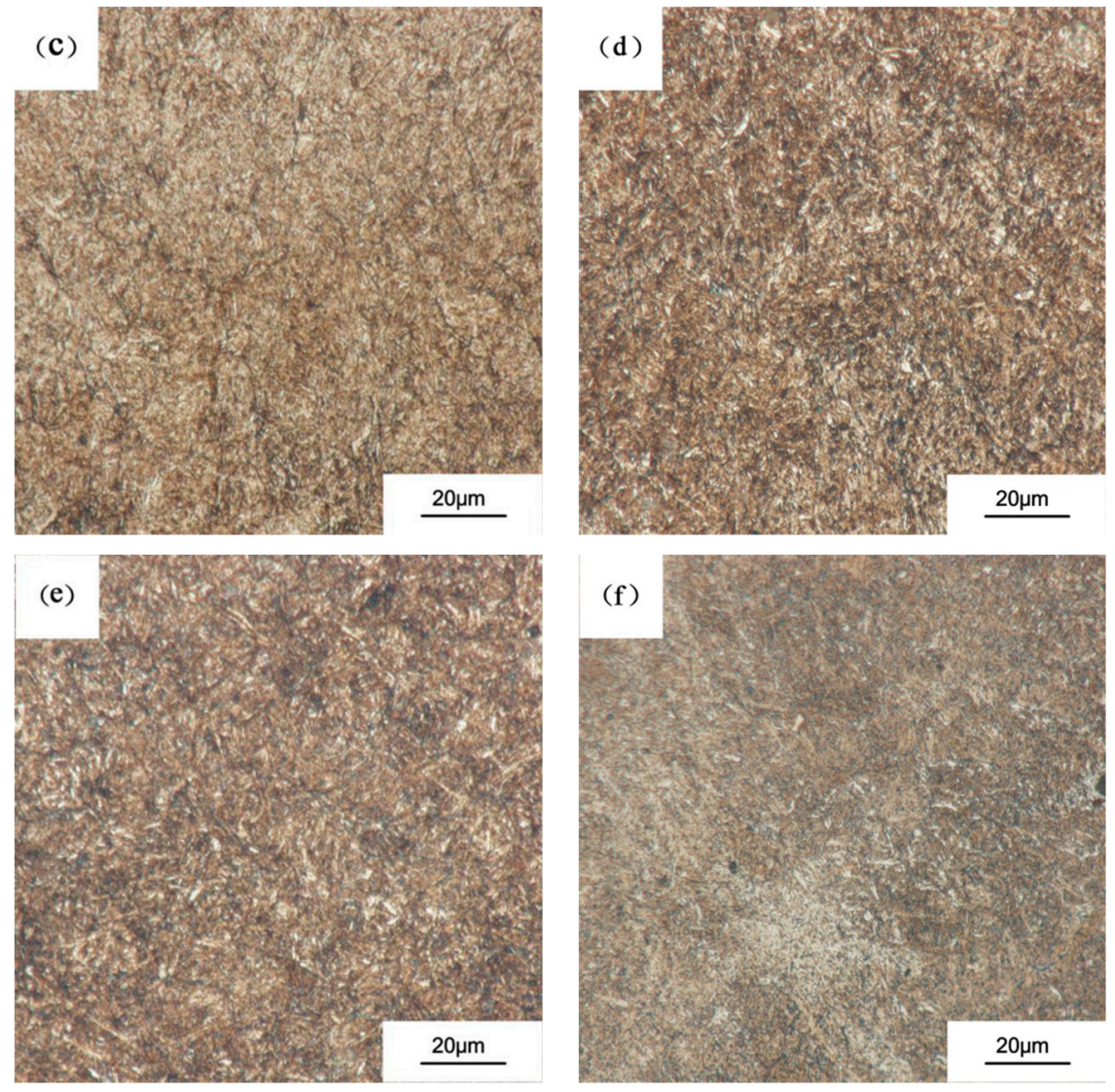

Figure 8. Microstructure of $\mathrm{H} 13$ steel after high temperature compression (a) $500{ }^{\circ} \mathrm{C},(\mathbf{b}) 600{ }^{\circ} \mathrm{C}$, (c) $630{ }^{\circ} \mathrm{C}$, (d) $6500{ }^{\circ} \mathrm{C}$, (e) $670{ }^{\circ} \mathrm{C}$, (f) $700{ }^{\circ} \mathrm{C}$.

\section{Conclusions}

The high temperature compression of $\mathrm{H} 13$ steel was conducted at the compression temperatures ranging from $100{ }^{\circ} \mathrm{C}$ to $700{ }^{\circ} \mathrm{C}$, with the strain rate at $0.01 \mathrm{~s}^{-1}$. The following conclusions could be summarized through the analysis on the compression curves, Rockwell hardness and microstructure:

During the high temperature compression, the compression strength decreased as the temperature increased. The reduction of the stress between $100{ }^{\circ} \mathrm{C}$ and $500^{\circ} \mathrm{C}$ was relatively small, the compression strength, the elastic limit and ductility decreased rapidly between $600^{\circ} \mathrm{C}$ and $700{ }^{\circ} \mathrm{C}$, and when the temperature was raised to $700{ }^{\circ} \mathrm{C}$, the ductility of the $\mathrm{H} 13$ steel was restored.

The hardness decreased with the increase of compression temperature, and the reduction of the hardness between $100{ }^{\circ} \mathrm{C}$ and $500{ }^{\circ} \mathrm{C}$ was relatively small. When the temperature reached over $600{ }^{\circ} \mathrm{C}$, the hardness decreased rapidly, and $\mathrm{HR}_{700}$ only reached $33.23 \mathrm{HRC}$.

The martensite in the material was decomposed when the temperature increased, the grain boundary segregation started to occur after $600^{\circ} \mathrm{C}$, which decreased the strength and ductility of the material. As the temperature continued to rise, the segregation grew, aggregated, spheroidized, and the ductility recovered.

Since $\mathrm{H} 13$ steel showed a sharp deterioration in properties after $600^{\circ} \mathrm{C}$, it is not recommended for TBM cutters to work in an environment of temperature over $600{ }^{\circ} \mathrm{C}$.

Author Contributions: Y.H., H.Z and J.T. conceived and designed the experiments; M.X. and M.W. (Mingze Wang) performed the experiments; M.W. (Maosen Wang) and A.Z. analyzed the data; J.T. wrote the paper.

Funding: This research was funded by the National Natural Science Foundation of China (No. 51875248) and the Science and Technology Development Project of Jilin Province (No. 20170204062G X and 20160301004G X).

Conflicts of Interest: The authors declare no conflict of interest. 


\section{References}

1. Toth, A.; Gong, Q.; Zhao, J. Case studies of TBM tunneling performance in rock-oil interface mixed ground. Tunn. Undergr. Space Technol. 2013, 38, 140-150. [CrossRef]

2. Zheng, Y.L.; Zhang, Q.B.; Zhao, J. Challenges and opportunities of using tunnel boring machines in mining. Tunn. Undergr. Space Technol. 2016, 57, 287-299. [CrossRef]

3. Armetti, G.; Migliazza, M.R.; Ferrari, F.; Berti, A.; Padovese, P. Geological and mechanical rock mass conditions for TBM performance prediction. The case of "La Maddalena" exploratory tunnel, Chiomonte (Italy). Tunn. Undergr. Space Technol. 2018, 77, 115-126. [CrossRef]

4. Zhao, J.; Gong, Q.M.; Eisensten, Z. Tunnelling through a frequently changing and mixed ground: A case history in Singapore. Tunn. Undergr. Space Technol. 2007, 22, 388-400. [CrossRef]

5. Belle, B.; Foulstone, A. Explosion Prevention in Coal Mine TBM Drifts-An Operational Safety Knowledge Share. Procedia Earth Planet. Sci. 2015, 11, 15-28. [CrossRef]

6. Bilgin, N.; Copur, H.; Balci, C. Effect of replacing disc cutters with chisel tools on performance of a TBM in difficult ground conditions. Tunn. Undergr. Space Technol. 2012, 27, 41-51. [CrossRef]

7. Gertscha, R.; Gertsch, L.; Rostamic, J. Disc cutting tests in Colorado Red Granite: Implications for TBM performance prediction. Int. J. Rock Mech. Min. Sci. 2007, 44, 238-246. [CrossRef]

8. Yagiz, S.; Karahan, H. Prediction of hard rock TBM penetration rate using particle swarm optimization. Int. J. Rock Mech. Min. Sci. 2011, 48, 427-433. [CrossRef]

9. Kang, M.; Park, G.; Jung, J.; Kim, B.-H.; Lee, Y.-K. The effects of annealing temperature and cooling rate on carbide precipitation behavior in $\mathrm{H} 13$ hot-work tool steel. J. Alloys Compd. 2015, 627, 359-366. [CrossRef]

10. Zhou, J.; Ma, D.-S.; Chi, H.-X.; Chen, Z.-Z.; Li, X.-Y. Microstructure and properties of hot working die steel H13MOD. J. Iron Steel Res. Int. 2013, 20, 117-125. [CrossRef]

11. Cui, X.H.; Wang, S.Q.; Wei, M.X.; Yang, Z.R. Wear Characteristics and Mechanisms of H13 Steel with Various Tempered Structures. J. Mater. Eng. Perform. 2011, 20, 1055-1062. [CrossRef]

12. Ning, A.G.; Guo, H.J.; Chen, X.C.; Wang, M.B. Precipitation Behaviors and Strengthening of Carbides in H13 Steel during Annealing. Mater. Trans. 2015, 56, 581-586. [CrossRef]

13. Ning, A.; Mao, W.; Chen, X.; Guo, H.; Guo, J. Precipitation Behavior of Carbides in H13 Hot Work Die Steel and Its Strengthening during Tempering. Metals 2017, 7, 70. [CrossRef]

14. Li, S.; Wu, X.; Chen, S.; Li, J. Wear Resistance of H13 and a New Hot-Work Die Steel at High temperature. J. Mater. Eng. Perform. 2016, 25, 2993-3006. [CrossRef]

15. Liu, J.H.; Wang, G.X.; Bao, Y.P.; Yang, Y.; Yao, W.; Gui, X.N. Inclusion Variations of Hot Working Die Steel H13 in Refining Process. J. Iron Steel Res. Int. 2012, 19, 1-7. [CrossRef]

16. Wei, M.X.; Wang, S.Q.; Wang, L.; Cui, X.H.; Chen, K.M. Effect of tempering conditions on wear resistance in various wear mechanisms of H13 steel. Tribol. Int. 2011, 44, 898-905. [CrossRef]

17. Yan, G.H.; Huang, X.M.; Wang, Y.Q.; Qin, X.G.; Yang, M.; Chu, Z.M.; Jin, K. Effects of heat treatment on mechanical properties of H13 steel. Met. Sci. Heat Treat. 2010, 52, 393-395. [CrossRef]

18. Wang, C.T.; Zhou, H.; Lin, P.Y.; Sun, N.; Guo, Q.C.; Zhang, P.; Yu, J.X.; Liu, Y.; Wang, M.X.; Ren, L.Q. The thermal fatigue resistance of vermicular cast iron coupling with $\mathrm{H} 13$ steel units by cast-in process. Mater. Des. 2010, 31, 3442-3448. [CrossRef]

(C) 2018 by the authors. Licensee MDPI, Basel, Switzerland. This article is an open access article distributed under the terms and conditions of the Creative Commons Attribution (CC BY) license (http:/ / creativecommons.org/licenses/by/4.0/). 